\title{
Corruption Hand Capture Operation (OTT) On Illegal Payments of Recommendation Permit Application Development In Telecommunication Tower Construction
}

\begin{abstract}
Wachid Aryanto $^{1}$ and Maryanto ${ }^{2}$
Abstract. This article aims to identify and analyze the corruption of extortion through hand operation to the request for consent on construction of telecommunication towers. The analysis in this study using the case study method, by understanding the phenomenon of corruption through hand operations in depth, exploring and elaboration. Results of research and discussion shows that reports of extortion became the basis for investigators to conduct hand operations. The investigation team was able to prove corruption based on the principle of legality and culpability laid down in Article 12 e of Act No. 20 of 2001 on Amendments to the Act No. 31 of 1999 on Corruption Eradication.

Keywords: Corruption; Extortion; Hand Operations.
\end{abstract}

\section{Introduction}

Corruption qualified into extraordinary crime. ${ }^{3}$ The desire of each society is citizenship and legal certainty to govern all aspects of life. Corruption has proven detrimental to the welfare of society in justice. ${ }^{4}$ Errors perspective in response to corruption affect public confidence in getting the deficit to the existing legal certainty.

Some modus operandi committed by perpetrators of corruption in line with the advancement of technology today. Foresight investigators to prove the existence of corruption is a necessity that is needed in preventing and combating corruption. One effort that is catching hand operation. Although the term Hand Capture Operation (OTT) being debated among experts criminal law, but the fact that the case OTT has become part of the law enforcement corruption.

Legal terms associated with Operation Seize the hand is caught red-handed in the juridical formulation of the Code of Criminal Procedure. Caught in the act was the arrest of a at the time was committing a crime, or immediately after some time the criminal act was done, or shortly afterwards called for by the general public as a person who did it, or if a moment later her found objects allegedly used to commit the criminal who shows that he is the culprit or participating in or aiding and abetting the crime. $^{5}$

Licensing law is a fertile gap of birth practice of bribery (extortion). The interests of the applicant, faced with the power of the licensor is a logical reason for the transactions

\footnotetext{
${ }^{1}$ Student of Master of Law, Universitas Islam Sultan Agung Semarang and Members of the Indonesian National Police (Polri), email wachidaryanto46@gmail.com

${ }^{2}$ Faculty of Law, UNISSULA Semarang

3 Chandra Project, Mengapa Korupsi Dianggap Sebagai Kejahatan yang Luar Biasa?, https://chandraproject.wordpress.com/2012/10/12/mengapa-korupsi-dianggap-sebagai-kejahatanyang-luar-biasa/, accessed Tuesday, January 15th, 2019 at at 13:55 pm.

${ }^{4}$ Considerations letter a of Act No. 20 of 2001 on Amendments to the Act No. 31 of 1999 on Corruption Eradication.

${ }^{5}$ Article 1 Point 19, the Code of Criminal Procedure.
} 
are unlawful. In the case of telecommunications tower construction, the applicant took care of all the requirements of both administrative and technical. So for the regional administration, the opportunity for issuing permits to be a factor prone to fraud office, to enrich themselves or others through illegal fees that are not based on the provisions of the legislation.

Based on the reality of the above, then this journal departs from the question of how corruption of extortion through hand operation to the request for consent on construction of telecommunication towers?

\section{Research methods}

Problems of administrative law licensing practices likely to lead to corruption, extortion through the competent authority to give permission. Hand operations is one method of proving the occurrence of bribery and bribery process, so this way is quite effective in the management of criminal investigations of corruption. To analyze the problem, the writer uses the case study method, which are to understand the phenomenon of corruption through hand operations in depth, even explored and elaboration. ${ }^{6}$ While the documents reviewed is the Resume Hand Capture Operation Corruption of extortion request permission recommendations, the alleged corruption in Sukoharjo district. Analysis of the authors emphasized the fact the investigation and decision of the judges who violate the case with article 12 paragraph e Law of the Republic of Indonesia Number 20 of 2001 on the Amendment of the Law of the Republic of Indonesia Number 31 of 1999 on Corruption Eradication.

\section{Results and Discussion}

In this paper cases in a study based on (1) Police Report Number: LP / A / 232 / V / 2018 / Java / Ditreskrimsus, dated May 25, 2018; (2) Investigation Order Letter No. Sprin.Sidik / 440 / V / 2018 / Reskrimsus, dated May 25, 2018; (3) Investigation Order Letter No. Sprin.Sidik / 454 / V / 2018 / Reskrimsus, May 30, 2018. As has become part of the investigation case management, the results of this study follow the existing format of the source document follows the case resumes.

\section{Anatomy Case ${ }^{7}$}

- Case

Alleged corruption Hand Capture Operations (OTT) on extortion to the request for consent on joint construction of telecommunication towers owned by PT. DT in Hamlet Kauman Village Mancasan, District Baki, Sukoharjo undertaken by brothers TH Bin (Alm) S as the Subdistrict-Head, Sukoharjo, as referred to in Article 12 e of Act No. 20 of 2001 regarding amendments to the Constitution Act No. 31 of 1999 on Corruption Eradication.

- Reported / Suspect: Br. TH Bin (Alm) S.

- Time and Place of Hand Capture Operation (OTT) On Wednesday On May 23, 2018, the Subdistrict-Head office, Sukoharjo.

\footnotetext{
${ }^{6}$ Yin, Robert K, 1994, Case Study Research. Thousand Oaks, London, New Delhi: SAGE Publications, h21

${ }^{7}$ Minutes of the Opinion, Corruption Hand Capture Operation (OTT) on extortion to the request for consent on construction of telecommunication towers, the Central Java Police, 2018.
} 
- Chronological Case

- On Tuesday, May 22, 2018 around 13:00 pm in the Office of Central Java Police Ditreskrimsus at Breadfruit Kingdom Street No.46 Banyumanik Semarang, receiving complaints from the public related objection to the charges made by $\mathrm{Br}$. $\mathrm{TH}$ as district head Tray Sukoharjo in handling applications on shared telecommunications tower construction permits owned by PT. DT in the HPD. Kauman RT 003 / RW 008 Mancasan Village district. Tray Sukoharjo.

- On Wednesday, May 23, 2018 around 13:30 pm o'clock later Investigation Team headed to the room Mr. Head, Br. TH, and really found no widespread extortion practices by Br. TH as Tray Sukoharjo district head and found an amount of US $\$$ 20,000,000.00 (twenty million) in a drawer belonging to Br. Related TH handling applications on shared telecommunications tower construction permits owned by PT. DT in Hamlet Kauman RT 003 / RW 008 Mancasan Village district. Tray Sukoharjo.

- Then around 13:50 pm Investigation Team brings Br. TH, Br. M. I and Br. Grogol ES to the Police for further investigation.

- Evidence :

- In accordance Warrant Foreclosure

No. Sprin.Sita / 80 / V / 2018 / Reskrimsus 25Mei dated 2018, has carried out the seizure of the form:

- 1 (one) bundle the Indonesian Government Regulation No. 17 of 2018 concerning the District;

- 1 (one) Reference bundle the District Licensing Regulations Recommendations Tray Year 2017;

- Two (2) copies of the Letter of recommendation on behalf of the District Tray TH, S. Sos., M.Sc. Bin (Alm) S, number: 600/239 / V / 2018;

- Two (2) copies of letter of recommendation from the Village Mancasan on behalf of S, dated May 7, 2018;

- 1 (one) concept of the District Recommendation Letter Tray No. 600 / V / 2018;

- 1 (a) Letter of Recommendation No. Subdistrict Tray; 600/68 / II / 2018 dated February 17, 2017 On the Establishment of a mobile Tower PT TB;

- Four (4) copies of the Statement Permit Citizen, dated May 7, 2018 which has been legallly by Camats Tray;

- Cash amounting to Rp 20,000,000, - (twenty million);

- Two (2) copies of an excerpt of Sukoharjo Regency Decree Number: 821.2 / 261/2016, dated December 30, 2018 on the appointment of the administrative office in Sukoharjo regency government environment to the TH brother, $S$. Sos., M.Sc. Bin (Alm) S and 1 (one) sheet Inaugural Statement Number: 821.2 / 05/2017, dated January 3, 2018;

- ES, SE (Acting (Acting Acting) Subsection Public and Civil Service in the district. Tray Sukoharjo

Confiscation Orders SesuaiSurat Number: Sprin.Sita / 80 / V / 2018 / Reskrimsus, dated May 25, 2018 has been seizure include:

- 1 (one) Agenda books Outgoing Mail Tray District of the Year 2017; 
- 1 (one) Agenda books Outgoing Mail District of Baki 2018.

- Drs.AM, MM, (as Head of Coding and Statistics),

Seizure Warrant accordance Number: Sprin.Sita / 80 / V / 2018 / Reskrimsus, dated May 5, 2018 has been seizure include: 1 (one) Check List the requirements for issuance of recommendation Establishment of Telecommunication Towers for the applicant.

- Article which presupposed

Article 12 paragraph e Law of the Republic of Indonesia Number 20 of 2001 on the Amendment of the Law of the Republic of Indonesia Number 31 of 1999 on Corruption Eradication.

The above case is one of corruption through Hand Capture Operation (OTT) on extortion. Exposure to these data suggests that:

\section{Case Position}

The suspect did extortion against the application for permission on construction of telecommunication towers in the work area under the authority of a suspect in establishing licensing law. Statement of witness states that permit the construction of telecommunications towers recommendations free of charge. Moreover refers Sukoharjo decree No. 73 of 2011 on Procedures and Requirements Issuance of building permit is free of charge. So the demand for Rp $20,000,000$ by the suspect, there is no legal basis set.

The incidence of corruption by means of abusing his power by a decree Sukoharjo Number: 821.2 / 261/2016 dated December 30, 2016 on the Appointment of the Occupation Administration Governments Sukoharjo district, ${ }^{8}$ with the intent of enriching himself or another person, unlawfully by issuing policies that are created and assigned with corresponding provisions applicable legislation which serve as the basic levy or force someone to give something or pay $\mathrm{Rp} 20,000,000.00$ related Technical Recommendation letter license manufacture in the construction of telecommunication towers, as referred to in Article 12 e of Act No. 20 of 2001 on Amendments to the Act No. 31 of 1999 on Corruption Eradication.

\section{Analysis}

According to the study authors Article 12 e of Act No. 20 of 2001 on Amendments to the Act No. 31 of 1999 on Corruption Eradication. Juridical formulation of the article as follows: ${ }^{9}$

"Punishable with imprisonment for life or imprisonment for a minimum of 4 (four) years and a maximum of 20 (twenty) years and fined at least Rp.200.000.000,00 (two hundred million rupiah) and at most $R p 1,000$ .000.000,00 (one billion rupiah)

(E) The civil servant or the conduct of the country with the intent of enriching himself or another person unlawfully, or by abusing his power to

\footnotetext{
${ }^{8}$ Sukoharjo Regency Decree Number: 821.2 / 261/2016 dated December 30, 2016 on the appointment of the administrative positions in Sukoharjo regency government Environment

${ }^{9}$ Article 12 e of Act No.20 of 2001 on Amendments to the Act No. 31 of 1999 on Corruption Eradication.
} 
force someone gives something, pay or accept payment by piece or to do something for himself".

The elements contained in the article include:

- Servants or State Officials

- With Profitable mean Yourself or Others

- By Unlawful or with Abusing His reign

- Forcing Someone give something, pay or accept payment by piece or to do something for himself

System due process of law in law enforcement in our country mandates the enforcement process is right and just, not on the basis of stigma especially hatred against citizens who are not necessarily guilty of anything suspected or alleged. ${ }^{10}$

As the substance of the law in a criminal offense there are always elements of actions in a criminal act. Basic principles in criminal offenses is the principle of legality and principle culpability. The principle of legality in criminal law set out in the Criminal Code article 1, paragraph (1), namely; (1) An act can not be convicted, except by the power of the criminal provisions of the legislation that has been there. ${ }^{11}$ Formulation juridical legality principle this means that said to include criminal acts if the act contained in the statutory provisions. Meanwhile in article Article 12 e of Act No. 20 of 2001 on the Amendment of Act No. 31 of 1999 on the Eradication of Corruption Act expressly formulate that (1) with the intent of enriching himself or others (2) against the law, or by abusing his power, (3) forcing someone gives something, pay or accept payment by piece or to do something for himself. ${ }^{12}$ The principle of the act which contains three of the above, simply to assert that a legal substance in the formulation of the juridical article is sufficient to satisfy the principle of legality of criminal provisions.

As culpability principle, namely the principle of error is a balancing of the principle of legal principles provides guidance that "nature against the law" contains the positive and negative balance. As the meaning of the formula, namely criminal offenses (principle of legality) and errors (principle culpability). ${ }^{13}$ In the discussion about the legal basis of corruption, then the investigator to prove that both the criminal elements as well as elements of the error committed by the perpetrators of corruption.

The process of investigation of corruption on illegal levies such, must be able to prove the offense set out in Article 12 e of Act No. 20 of 2001 on Amendments to the Act No. 31 of 1999 on Corruption Eradication, based on two principles of good legality and culpability.

\footnotetext{
10 Yusril Ihza Mahendra, Fenomena Praperadilan, Yusril: Ini Makna dari ?Due Process Of Law?. http://www.aktual.com/fenomena-praperadilan-yusril-ini-makna-dari-due-process-of-law/, accessed Wednesday, November 1st, 2018 at 20:51 pm.

${ }^{11}$ Article 1, paragraph (1) of the Criminal Justice Act

${ }^{12}$ Article 12 e of Act No. 20 of 2001 on Amendments to the Act No. 31 of 1999 on Corruption Eradication

${ }^{13}$ Youtube, Barda Nawawi Arif, 2013, Tipikor, Pelatihan Tematik Bagi Hakim di Peradilan Militer,Komisi Yudisial, https://www.youtube.com/watch?v=ZEEN9LaCRwg, accessed on Thursday, November 1st, 2018 at 7:53 pm.
} 
Proof by investigators in the corruption case of the illegal charges, explain the following matters:

- The suspect is Servants or State Officials

Evidence gathered is that the suspects are appointed and designated as the District Subdistrict Baki, Sukoharjo district based Sukoharjo Regency Decree Number: 821.2 / 261/2016 dated December 30, 2016 concerning the appointment of the administrative office in Sukoharjo regency government environment. So suspect as Subdistrict-Head, Sukoharjo district has met the elements of Article Servants or State Officers in this case.

- With Profitable mean Yourself or Others

Evidence that the District as the District Head Baki, Sukoharjo, the suspect asked for a fee of Rp. 20.000.000, - (twenty million) to the relatives of the brothers MII (PT DMT) related to the construction permit Telecommunications tower located in Ds Mancasan, District Baki, Sukoharjo in Central Java. Recognition of the suspect as Tray Regency Sukoharjo district sub-district request letters of recommendation related costs of making telecommunications tower construction Rp. 20.000.000, (twenty million rupiahs). Thus the favorable elements for the purpose of Yourself or Others met.

- By Unlawful or with Abusing His reign

In Act No. 5 of 2014 concerning the State Civil Apparatus civil servants based on the PP 53 of 2010 on Discipline of Civil Servants for civil servants prohibition set out in Article 4, which reads that every civil servant is prohibited: (a) Misuse of authority. ${ }^{14}$ Thus the element of abuse of authority or unlawful (acts that are prohibited in the disciplines of Civil Servants) are met.

- Forcing Someone give something, pay or accept payment by piece or to do something for himself.

The suspect as Tray subdistrict district. Sukoharjo in issuing or provide a letter of recommendation to you MII (PT DMT) request, charging a fee of Rp 20,000,000, and in accordance with the recognition of the suspect. Then the element ?? Forcing Someone give something, pay or accept payment by piece or to do something for himself ?? fulfilled.

Thus the substance of the law contained in Article 12 e of Act No. 20 of 2001 on Amendments to the Act No. 31 of 1999 on Corruption Eradication, has been proven through the testimony of witnesses, the evidence and confessions of suspects. This element of the principle of legality expressed by the phrase ?? unlawful ?? can easily be met by the fact that the organizer of State (Civil Service), the prohibition of misuse of authority is a proof of hits principle of legality in criminal acts of this korupi. In addition culpability principle, in cases of corruption of these illegal charges, can easily be proved because of the report from the complainant (victim) extortion later proved by police with hand operations.

\footnotetext{
${ }^{14}$ Article 4 of Government Regulation No. 53 of 2010 on Discipline of Civil Servants.
} 
The case has become a legal decision remains with the sentence of the court of corruption three years imprisonment, a fine of 200 million subsidiary six months confinement and evidence Rp 20,000,000, - confiscated for the State. ${ }^{15}$

\section{Closing}

\subsection{Conclusion}

Departing from the original question writer is how corruption of extortion through Hand Capture Operation to the request for consent on construction of telecommunication towers? So the conclusion in the case of corruption on wild through Hand Capture Operations of the police, showed that reports of extortion became the basis for investigators to conduct hand operations. The investigation team was able to prove corruption based on the principle of legality and culpability laid down in Article 12 e of Act No. 20 of 2001 on Amendments to the Act No. 31 of 1999 on Corruption Eradication. The court sentenced the defendant three years imprisonment, a fine of $\mathbf{2 0 0}$ million subsidiary six months confinement and evidence Rp 20,000,000,

\section{Suggestion}

The author suggests a cumulative sentence based not merely an alternative. Because the crime of corruption is a criminal offense is outstanding, so the deterrent effect of the intent in the Corruption Act can be met.

\section{Bibliography}

[1] Berita Acara Pendapat, Tindak Pidana Korupsi Kegiatan Operasi Tangkap Tangan (OTT) tentang Pungutan Liar pada Permohonan Rekomendasi Izin Pembangunan Menara Telekomunikasi, Polda Jateng, 2018.

[2] Chandra Project, Mengapa Korupsi Dianggap Sebagai Kejahatan yang Luar Biasa?,https://chandraproject.wordpress.com/2012/10/12/mengapakorupsi-dianggap-sebagai-kejahatan-yang-luar-biasa.

[3] Solopos.com, Eks Camat Baki Sukoharjo Kena OTT Pungli Divonis 3 Tahun Penjara, https://soloraya.solopos.com/read/20181024/490/948134/eks-camatbaki-sukoharjo-kena-ott-pungli-divonis-3-tahun-penjara.

[4] Yin, Robert K, 1994, Case Study Research, Thousand Oaks, London, New Delhi: SAGE Publications

[5] Youtube, Barda Nawawi Arif, 2013, Tipikor, Pelatihan Tematik Bagi Hakim di Peradilan Militer,Komisi Yudisial, https:// www. youtube.com/watch?v=ZEEN9LaCRwg

15 Solopos.com, Eks Camat Baki Sukoharjo Kena OTT Pungli Divonis 3 Tahun Penjara, https://soloraya.solopos.com/read/20181024/490/948134/eks-camat-baki-sukoharjo-kena-ott-punglidivonis-3-tahun-penjara,, accessed on Tuesday, January 15th, 2019 at $15: 14$ pm. 
[6] Yusril Ihza Mahendra, Fenomena Praperadilan, Yusril: Ini Makna dari ?Due Process Of Law?. http://www.aktual.com/fenomena-praperadilan-yusril-inimakna-dari-due-process-of-law/

[7] The Code of Criminal Procedure

[8] Book of the Criminal Justice Act.

[9] Government Regulation No. 53 of 2010 on Discipline of Civil Servants

[10] Act No. 20 of 2001 on Amendments to the Act No. 31 of 1999 on Corruption Eradication

[11] Sukoharjo Regency Decree Number: 821.2 / 261/2016 dated December 30, 2016 on The Appointment of The Administrative Positions In Sukoharjo Regency Government Environment. 